\title{
COMISSÃO DE CORRETAGEM EM COMPRA E VENDA SUBMETIDA À INCORPORAÇÃO IMOBILIÁRIA QUEM DEVE PAGAR?
}

Luciana Pedroso Xavier* Adroaldo Agner Rosa Neto**

Sumário: Introdução - 1. O entendimento do STJ antes do REsp 1.599.511/SP 2. O julgamento do REsp 1.599.511/SP - 3. Comentários críticos - Considerações finais - Referências.

\section{INTRODUÇÃO}

O presente artigo é fruto das discussões travadas no painel de Contratos do XV Encontro de Grupos de Pesquisa em Direito Civil da Universidade Estadual do Rio de Janeiro, da Universidade Federal do Paraná, da Universidade Federal de Pernambuco e da Universidade de São Paulo, realizado no início de junho de 2017 na Faculdade de Direito do Largo de São Francisco.

No ensejo de adotar um formato de evento que propiciasse uma troca de ideias mais frutífera entre os membros dos grupos, para cada painel foi escolhido um julgado relevante advindo de um dos Tribunais Superiores para nortear os trabalhos.

\footnotetext{
* Doutora e Mestre pelo Programa de Pós-Graduação da Faculdade de Direito da UFPR. Professora substituta de Direito Civil na Faculdade de Direito da UFPR. Professora do Unicuritiba. Advogada em Curitiba. Pesquisadora do Núcleo de Estudos em Direito Civil Constitucional Virada de Copérnico.

** Advogado em Curitiba. Bacharel em Direito pela Faculdade de Direito da UFPR. Pesquisador no Núcleo de Estudos em Direito Civil Constitucional - Virada de Copérnico.
} 
Por se tratar de um Encontro longevo, contabilizando 15 edições, optou-se por adotar um modelo que possibilitasse maior diálogo entre os participantes e, ao mesmo tempo, o aprofundamento dos temas examinados. A edição e publicação de seus anais coroam o sucesso do evento, oportunidade em que se expressa gratidão pela calorosa acolhida dos amigos "das Arcadas".

$\mathrm{Na}$ mesa destinada ao estudo dos contratos, foi eleito o Recurso Especial n. 1.599.511/SP, o qual, juntamente com outros quatro, foi escolhido como representativo de controvérsia pelo Superior Tribunal de Justiça, tendo sido afetado ao julgamento do tema/repetitivo n. 938. O REsp 1.559.511/SP trata da possibilidade de repassar o dever de pagamento da comissão de corretagem para o consumidor adquirente de imóvel objeto de incorporação imobiliária, bem como da cobrança pelo promitente-vendedor da taxa pelo serviço de assessoria técnico-imobiliária (SATI).

Cabe ressaltar que a escolha do julgado foi muito oportuna ante a importância social da controvérsia, uma vez que esse se encontra ligado ao direito fundamental e social à moradia. Igualmente, o grande número de ações que na época tramitava no país (contabilizavam-se mais de 15 mil processos) ${ }^{1}$ justificava um enfrentamento pelo Superior Tribunal de Justiça voltado para uniformizar a interpretação dessa questão.

Dada a riqueza de prismas pelos quais esses temas podem ser explorados, cada pesquisador elegeu o seu recorte. No caso dos autores, a opção foi por dar ênfase na fundamentação da decisão e nas insuficiências existentes na tese jurídica firmada a partir do julgamento do referido Recurso. Para tanto, iniciar-se-á pela análise da jurisprudência do STJ antes da afetação, com o objetivo de analisar qual exatamente era a posição da Corte acerca do assunto.

Em seguida, é examinado o REsp 1.599.511/SP, para o fim de se averiguar o motivo pelo qual ocorreu a sua afetação, qual foi a decisão proferida pelo STJ, em que termos ocorreu (se por unanimidade ou maioria) e quais os argumentos utilizados na sua fundamentação.

Em prosseguimento, são tecidas consideração críticas sobre a fundamentação da decisão e a elaboração da tese jurídica firmada no aludido Recurso, com ênfase na suficiência ou não do cumprimento do dever de informação ao consumidor pelo promitente-vendedor.

Por fim, são apresentadas as considerações finais e apontamentos prospectivos acerca do REsp 1.601.149/RS, o qual ainda está pendente de julgamento e versa

\footnotetext{
As informações estão disponíveis em: <http://www.stj.jus.br/repetitivos/temas_repetitivos/ pesquisa.jsp>. Acesso em: 18. abr. 2018.
} 
sobre a cobrança de comissão de corretagem em aquisições realizadas no âmbito do programa Minha Casa, Minha Vida.

\section{O ENTENDIMENTO DO STJ ANTES DO RESP 1.599.511/SP}

Os temas debatidos no REsp 1.599.511/SP - a possibilidade ou não de transferência da comissão de corretagem ao consumidor e a validade da cobrança da taxa SATI - há tempos são pontos controvertidos na jurisprudência dos Tribunais Estaduais. $^{2}$

Para compreender o posicionamento que o STJ adotava antes do julgamento do recurso em comento, realizou-se pesquisa em sua base de decisões. Como critério temporal, fixou-se o período referente aos três anos anteriores à afetação do REsp 1.551.956/SP (primeiro recurso a ser afetado ao tema n. 938), ocorrida em 08.09.2015. Os critérios materiais foram os assuntos debatidos: (i) cobrança de comissão de corretagem na compra e venda de imóvel na planta, e (ii) a validade da cobrança da taxa SATI. Utilizaram-se os termos "comissão de corretagem" e "taxa SATI" na busca de cada um dos critérios materiais, restrita à sua ocorrência na ementa/indexação. A pesquisa resultou em 43 ocorrências para o primeiro critério e nenhuma para o segundo.

No primeiro critério, ou seja, o da comissão de corretagem, apenas 11 dessas ocorrências ${ }^{3}$ tratavam da matéria aqui discutida. As outras 32 ocorrências tratavam, em sua maioria, ou de cobrança de comissão de corretagem por corretor particular ou de comissão de corretagem em seguros, não guardando pertinência com o tema investigado.

Nas 11 ocorrências em que a questão de fato foi a discussão sobre a transferência do pagamento da comissão de corretagem ao consumidor na compra e venda de imóvel na planta, houve negativa de seguimento aos recursos especiais.

2 Pode-se citar, apenas a título de exemplo, decisões diametralmente opostas proferidas em datas muito próximas nos Tribunais de Justiça do Paraná e de São Paulo: Apelação Cível n. 11835799 do TJPR, rel. Denise Krüger Pereira, j. 15.07.2015, reconhecendo ilegalidade da transferência; Apelação Cível n. 1359526-7 do TJPR, rel. Prestes Mattar, j. 21.07.2015, reconhecendo a legalidade da transferência; Apelação Cível n. 1010810-80.2014.8.26.056 do TJSP, rel. José Aparício Coelho Prado Neto, j. 04.08.2015, reconhecendo a legalidade da transferência; Apelação Cível n. 0010376-07.2012.8.26.0008 do TJSP, rel. Airton Pinheiro de Castro, j. 27.07.2015, reconhecendo a ilegalidade da transferência.

3 Trata-se dos recursos AgRg no AREsp 316936/RJ, AgRg no AREsp 699002/SP, AgRg no AREsp 690181/RJ, AgRg no AREsp 746601/RJ, AgRg no REsp 1454248/RJ, AgRg no AREsp 685109/SP. AgRg no AREsp 636628/RJ, AgRg no AREsp 609315/DF, AgRg no AREsp 592334/DF, AgRg no AREsp 502177/RJ e AgRg no AREsp 269915/RJ. 
A argumentação foi de que a análise da abusividade desse pagamento demandaria o reexame de cláusulas contratuais e/ou o reexame de provas, o que seria vedado pelas Súmulas $5^{4}$ e $7^{5}$ do STJ.

No segundo critério, o da validade da taxa SATI, a pesquisa não encontrou nenhuma ocorrência dentro do critério temporal estabelecido. Isso não significa que o STJ tenha deixado de enfrentar o tema. Provavelmente o fez, mas de maneira que o termo "taxa SATI" não constasse na ementa ou na indexação. De todo modo, parece razoável supor que a análise da taxa SATI segue a mesma sorte da análise da cláusula de corretagem no entendimento do STJ: a negativa do seguimento do recurso em razão da vedação das Súmulas 5 e 7.

A partir dessa breve pesquisa, é possível fazer dois apontamentos sobre o entendimento do STJ antes do julgamento do REsp 1.551.956/SP. O primeiro é a sinalização, ainda que de forma implícita, que a transferência do pagamento da taxa de corretagem ao consumidor em compra e venda de imóveis na planta é matéria eminentemente contratual, fato que, como veremos, coaduna-se com o voto do Min. Paulo de Tarso Sanseverino, na relatoria dos recursos repetitivos, quando argumenta que as incorporadoras podem repassar aos consumidores o dever de arcar com a comissão de corretagem, pois trata-se de ambiente de Direito Privado, prevalecendo a autonomia das partes.

O segundo, em verdade, é um questionamento: se a matéria é eminentemente contratual, de que forma acabou se tornando objeto de julgamento de recursos repetitivos em Corte cuja competência constitucional é a uniformização da aplicação da legislação federal?

Cumpre mencionar o voto do Min. João Otávio de Noronha, no REsp 1.288.450/AM, julgado em 24.02.2015, que, apesar de não tratar sobre corretagem na compra e venda de imóveis na planta, é marco nessa transição entre o entendimento até então esboçado e o julgamento do tema/repetitivo n. 938.

No REsp 1.288.450/AM, ao se analisar o contrato verbal de corretagem, entendeu-se que o incumbente é o responsável pelo pagamento do corretor, afastando tentativa de aplicação do art. 490 do Código Civil de 2002 ao caso ali discutido, que deixa a cargo do comprador despesas de escritura e registro. Interessante notar que o voto já indicava o futuro entendimento da Corte, ao consignar que a regra geral impõe ao incumbente o pagamento da corretagem, "salvo estipulação das

4 Súmula 5 do Superior Tribunal de Justiça: “A simples interpretação de cláusula contratual não enseja recurso especial".

5 Súmula 7 do Superior Tribunal de Justiça: "A pretensão de simples reexame de prova não enseja recurso especial". 
partes”. Na prática, isso equivale a autorizar às partes da negociação o ajuste entre si do pagamento da taxa de corretagem.

Assim, em resumo, pode-se afirmar que o STJ, antes do julgamento do tema/ repetitivo n. 938, não abordou de forma direta a quem incumbiria arcar com a comissão de corretagem do imóvel objeto de incorporação imobiliária, restringindo ao âmbito dos Tribunais Estaduais as discussões sobre a matéria.

\section{O JULGAMENTO DO RESP 1.599.511/SP}

O Recurso Especial n. 1.599.511/SP, como visto, é um dos recursos que compuseram julgamento mais amplo, feito pelo STJ no tema/repetitivo n. 938, cuja relatoria coube ao Min. Sanseverino. Ao todo, foram selecionados cinco recursos como representativos de controvérsia, são eles: REsp 1.551.956/SP, REsp 1.599.510/ SP, REsp 1.599.511/SP, REsp 1.599.618/SP, REsp 1.602.800/DF. ${ }^{6}$

No tema/repetitivo n. 938, três questões foram submetidas a julgamento: (i) prescrição da pretensão de restituição das parcelas pagas a título de comissão de corretagem e de assessoria imobiliária, sob o fundamento da abusividade da transferência desses encargos ao consumidor; (ii) validade da cláusula contratual que transfere ao consumidor a obrigação de pagar comissão de corretagem de imóvel adquirido na planta; e (iii) validade da cobrança da taxa de assessoria técnico-imobiliária (SATI).

A decisão do relator determinando a suspensão de todas as açôes em trâmite, inclusive no primeiro grau, que versassem sobre as questóes de direito que foram objeto de afetação foi publicada em 18.12.2015. Ao todo, foram suspensos 15.654 processos até o julgamento do tema.

O STJ realizou, em 09.05.2016, audiência pública ${ }^{7}$ da qual participaram representantes de entidades ligadas à matéria debatida. Além disso, os Professores

\footnotetext{
6 O STJ mantém mecanismo de busca específico para os Recursos Repetitivos e Incidentes de Assunção de Competência em seu sítio eletrônico, trazendo informações detalhadas sobre a numeração dos temas, situação, ramo do direito, assunto, questão submetida a julgamento, tese firmada, informações complementares, grupos de processos afetados e número de processos suspensos. As informações apresentadas neste item sobre o tema em comento estão disponíveis no seguinte link: <http://www.stj.jus.br/repetitivos/temas_repetitivos/pesquisa. jsp>. Acesso em: 18. abr. 2018.

7 A audiência pública está disponível na íntegra no espaço mantido pelo STJ no site de compartilhamento de vídeos YouTube, no seguinte link: <https://www.youtube.com/ watch?v=Q09dwudg9RA >. Acesso em: 20. abr. 2018. A programação da audiência pode ser encontrada na revista eletrônica Consultor Jurídico: <https://www.conjur.com.br/2016-mai-09/stj-debate-legalidade-cobranca-taxas-venda-imovel>. Acesso em: 20. abr. 2016.
} 
Araken de Assis, Ada Pellegrini Grinover, Bruno Miragem, Cláudia Lima Marques, Gustavo Franco e Humberto Theodoro Júnior emitiram parecer em favor da tese sustentada pelas incorporadoras; a Professora Judith Martins-Costa e o advogado Gustavo Haical emitiram parecer em favor da tese sustentada pelos consumidores, todos colacionados aos autos.

O julgamento do tema/repetitivo n. 938 foi realizado em conjunto com o de n. 939 (que versava sobre a legitimidade passiva das incorporadoras para figurarem nas ações de repetição de indébito das taxas de corretagem e SATI), em 26.08.2016; mas apenas os REsp 1.599.511/SP, REsp 1.551.956/SP (tema n. 938), REsp 1.551.951/SP e REsp 1.551.968/SP (tema n. 939) serviram de objeto de discussão. Os outros sofreram desafetação após as teses terem sido firmadas.

No tema n. 938, firmaram-se as seguintes teses: (i) incidência da prescrição trienal sobre a pretensão de restituição dos valores pagos a título de comissão de corretagem ou de serviço de assistência técnico-imobiliária (SATI), ou atividade congênere (artigo 206, S 30, IV, CC) (REsp 1.551.956/SP); (ii) validade da cláusula contratual que transfere ao promitente-comprador a obrigação de pagar a comissão de corretagem nos contratos de promessa de compra e venda de unidade autônoma em regime de incorporação imobiliária, desde que previamente informado o preço total da aquisição da unidade autônoma, com o destaque do valor da comissão de corretagem (REsp 1.599.511/SP); (iii) abusividade da cobrança pelo promitente-vendedor do serviço de assessoria técnico-imobiliária (SATI), ou atividade congênere, vinculado à celebração de promessa de compra e venda de imóvel (REsp 1.599.511/SP).

Como dito, a análise empreendida aqui está restrita ao REsp 1.599.511/SP, de modo que não se abordará a questão da prescrição que, por sua complexidade, merece tratamento em apartado. Igualmente não será enfrentada a problemática da legitimidade da incorporadora, discutida no tema n. 939.

No voto do REsp 1.599.511/SP, o Min. Relator, após analisar a natureza jurídica do contrato de corretagem, conclui que, em princípio, cabe ao incumbente pagar a comissão de corretagem. Em tese, portanto, seria dever da incorporadora pagar os corretores que disponibiliza em seu stand de vendas.

Todavia, deixando claro que a questão se situa no âmbito do Direito Privado, completa o Min. Sanseverino que "naturalmente [...] pode haver a transferência desse encargo, mediante cláusula expressa no contrato principal, à outra parte interessada no negócio". ${ }^{8}$ Pois, nos termos do voto, o Direito do Consumidor, apesar

8 Todas as citações entre aspas ou com recuo, que não possuam referência diversa no rodapé, foram extraídas do voto do Min. Sanseverino no julgamento do REsp 1.559.511/SP. 
do caráter protecionista, não subverte "[...] a natureza onerosa das relações negociais no mercado de consumo [...]".

Ainda, segundo o Relator, essa transferência deve observar o dever de informação, contido nos arts. 31, 46 e 52 do CDC e no Decreto n. 5.903/2006, seja nas vendas a prazo - como usualmente ocorre no mercado imobiliário -, seja nas vendas à vista. A validade da cláusula que transfere o pagamento da comissão de corretagem ao consumidor depende, portanto, da informação clara, "[...] até o momento da celebração do contrato, acerca do preço total da unidade imobiliária, incluído nesse montante o valor da comissão de corretagem".

Consignou-se no voto que a violação desse dever de informação impõe a incidência do art. 30 do CDC, ${ }^{9}$ segundo o qual o consumidor terá direito de exigir o cumprimento da proposta pelo preço ofertado. Logo, sem previsão expressa no contrato, não é possível a cobrança da taxa de corretagem. Caso haja recusa da incorporadora em cumprir a proposta, o consumidor poderá exigir o cumprimento forçado da obrigação, nos termos do art. 35 do CDC. ${ }^{10}$

No que toca à taxa SATI, entendeu o STJ que a cláusula que a contém é abusiva; em primeiro lugar, pelos serviços prestados serem inerentes ao contrato celebrado e, em segundo lugar, por ser o serviço de assessoria personalíssimo.

Feito esse relato acerca do julgamento do REsp 1.559.511/SP, torna-se possível tecer os comentários críticos pertinentes, o que se faz no próximo item do presente estudo.

\section{COMENTÁRIOS CRÍTICOS}

A questão dos imóveis residenciais sempre possuiu imensa repercussão social e econômica no Brasil ${ }^{11}$. Exemplo disso é a obra do grande sociólogo Gilberto

9 Art. 30 do Código de Defesa do Consumidor: "Toda informação ou publicidade, suficientemente precisa, veiculada por qualquer forma ou meio de comunicação com relação a produtos e serviços oferecidos ou apresentados, obriga o fornecedor que a fizer veicular ou dela se utilizar e integra o contrato que vier a ser celebrado".

10 Art. 35 do Código de Defesa do Consumidor: "Se o fornecedor de produtos ou serviços recusar cumprimento à oferta, apresentação ou publicidade, o consumidor poderá, alternativamente e à sua livre escolha: I - exigir o cumprimento forçado da obrigação, nos termos da oferta, apresentação ou publicidade; II - aceitar outro produto ou prestação de serviço equivalente; III - rescindir o contrato, com direito à restituição de quantia eventualmente antecipada, monetariamente atualizada, e a perdas e danos".

11 Nesse sentido, Rodrigo Xavier Leonardo afirma que "a habitação constitui um bem voltado para a satisfação de uma necessidade básica do sujeito, qual seja, a moradia”. LEONARDO, Rodrigo Xavier. Redes Contratuais no mercado habitacional. São Paulo: RT, 2003, p. 38. Sobre 
Freyre, da qual se extrai frase antológica sobre o tema: “[t]er casa-casa própria-é ideal de quase todo brasileiro: mesmo que seja o que às vezes por modéstia se define como um mucambinho, visita bem acolhida: 'a casa é sua". ${ }^{12}$

Tal fato, por óbvio, não poderia deixar de apresentar contornos jurídicos. Basta lembrar, $v$. $g$., as diversas Leis que buscaram regular as locações de imóveis no País ao longo do século passado, adequando-se aos valores e necessidades de cada época, ora tutelando mais os interesses dos locadores, ora dos locatários.

O tema da compra e venda de imóveis na planta, em específico, ganhou relevo nos últimos 12 anos, embalado pelo crescimento econômico experimentado no Brasil. No ano de 2014, o mercado imobiliário alcança o ápice do período, quando foram financiados 538,3 mil imóveis. ${ }^{13}$

A crise político-econômica, vivenciada no País a partir do final de 2014, acabou representando um "abafamento" no boom imobiliário registrado até então. O ano de 2015 terminou com uma queda de $33 \%$ nos valores envolvidos nesse mercado com relação ao ano anterior. Foram financiadas apenas 342 mil unidades. ${ }^{14}$

A diminuição no número de novos financiamentos foi acompanhada do crescimento no número de inadimplementos nos financiamentos já existentes. No ano de 2009, o equivalente a R \$ 1,2 bilhão em contratos de financiamento estavam em risco por falta de pagamento; no ano de 2017, esse número superou os R \$ 8 bilhôes. ${ }^{15}$

Esse breve panorama socioeconômico consegue transmitir o impacto que julgamentos como o do REsp 1.559.511/SP proporcionam no dia a dia da população. Isso explica a participação de entidades como a Associação Brasileira de Incorpora-

o direito fundamento à moradia, cf. PONTES, Daniele Regina. O direito à moradia: entre o tempo e o espaço das apropriaçôes. 2013. Tese (Doutoramento em Direito). Faculdade de Direito, Universidade Federal do Paraná. Curitiba - Paraná, 2013, $215 f$.

12 FREYRE, Gilberto. Oh de casa! em torno da casa brasileira e de sua projeção sobre um tipo nacional de homem. Rio de Janeiro: Artenova, 1979, p. 26 (grifou-se).

$13 \mathrm{O}$ auge e a queda do mercado imobiliário em uma década. G1. 01.04.2016. Disponível em: <http://g1.globo.com/especial-publicitario/zap/imoveis/noticia/2016/04/o-auge-equeda-do-mercado-imobiliario-em-uma-decada.html>. Acesso em: 21 abr. 2018.

14 O auge e a queda do mercado imobiliário em uma década. G1. 01.04.2016. Disponível em: <http://g1.globo.com/especial-publicitario/zap/imoveis/noticia/2016/04/o-augee-queda-do-mercado-imobiliario-em-uma-decada.html>. Acesso em: 21 abr. 2018.

15 MENEZES, Fabiane Ziolla. Cresce a retomada de imóveis por inadimplência. Saiba como escapar dessa. Gazeta do Povo, 05.04.2017. Disponível em: <http://www.gazetadopovo.com. br/economia/financas-pessoais/cresce-a-retomada-de-imoveis-por-inadimplencia-saiba-como-escapar-dessa-8g7e4h81212c79jwqlh8x6nfo>. Acesso em: 21 abr. 2018. 
doras Imobiliárias - ABRAINC, o Conselho Federal de Corretores de Imóveis COFECI, o Instituto Brasileiro de Defesa do Consumidor, o Instituto Potiguar de Defesa dos Consumidores - IPDCON, o Sindicato da Indústria da Construção Civil do Estado do Rio Grande do Norte, o Sindicato das Empresas de Compra, Venda, Locação e Administração de Imóveis Residenciais e Comerciais de São Paulo, a Associação Cidade Verde - ACV, a Câmara Brasileira da Indústria da Construção Civil, o Sindicato da Indústria da Construção Civil da Grande Florianópolis - SINDUSCON-FPOLIS, a Defensoria Pública da União e a própria União Federal, na qualidade de amici curiae no julgamento. Explica, também, os pareceres de importantíssimos jurisconsultos brasileiros, cujos nomes já foram citados.

Tais pareceres apresentaram argumentos relevantes, tanto pela invalidade da cláusula que transfere ao consumidor o pagamento da comissão de corretagem e da taxa SATI quanto pela sua validade.

Porém, tem-se que toda essa densidade teórica e social não ficou perfeitamente refletida nos termos da fundamentação utilizada no julgamento do recurso em comento, como se argumentará a partir de agora.

Do ponto de vista estrutural, a fundamentação do voto do Min. Sanseverino divide-se em quatro partes, a saber: (i) a natureza jurídica do contrato de corretagem no Código Civil; (ii) a especificidade da corretagem na compra e venda de unidades autônomas em incorporação imobiliária; (iii) o dever de informação imposto ao fornecedor; e (iv) o serviço de assessoria técnico-imobiliária; estas, por seu turno, subdividias em outras menores.

Na primeira parte, o voto valeu-se de citaçôes legislativas e doutrinárias, apontando a natureza do contrato de corretagem, enfatizando a refinada controvérsia doutrinária acerca da parcialidade ou não do corretor na atividade de intermediação, para concluir que, de "[...] todo modo, a solução da controvérsia posta no presente processo não se situa nesse ponto".

Prosseguindo na investigação, o voto estabeleceu, também com apoio na doutrina e na jurisprudência daquela Corte, que o devedor da comissão de corretagem é o incumbente, mas trazendo o primeiro indicativo e, no sentir desses autores, um dos verdadeiros fundamentos da decisão, ao afirmar que "[n]aturalmente, como a questão situa-se no plano do Direito Privado, pode haver a transferência desse encargo, mediante cláusula expressa no contrato principal, à outra parte interessada no negócio jurídico" (grifou-se).

Esta afirmação poderia parecer ilógica se descontextualizada, já que a outra parte do contrato de corretagem, que não o incumbente, é o próprio corretor. Mas, nos termos do voto, restou claro que "à outra parte interessada no negócio jurídico" 
é o terceiro comprador e que esse negócio jurídico é a compra e venda realizada com aquele que é o incumbente no contrato de corretagem.

Com isso, tem-se o início da segunda parte do voto, na qual se analisou a especificidade da comissão de corretagem na compra e venda em incorporação imobiliária. Aqui o voto descreveu bem a praxe encontrada no cotidiano: o consumidor vai até o stand de venda da incorporadora e é atendido por um corretor previamente contratado por esta e então

[a] lcançado o êxito na intermediação, a incorporadora, ao celebrar o contrato de promessa de compra e venda, transfere para o promitente-comprador a obrigação de pagar a comissão de corretagem diretamente ao corretor, seja mediante cláusula expressa no instrumento contratual, seja por pactuação verbal ou mediante a celebração de um contrato autônomo entre o consumidor e o corretor.

O voto citou a manifestação da Fazenda Nacional nos autos, corroborando com o cenário descrito, acrescentando que, em muitas ocasiões, “[...] a Receita Federal apurou que, somente após a concretização da venda, é celebrado um contrato de intermediação [...]". Mais adiante afirmou que essa transferência é vantajosa às incorporadoras, na medida em que reduziria a base de cálculo dos tributos incidentes sobre a aquisição dos imóveis. ${ }^{16}$

O Min. Relator apresentou o entendimento da Corte no REsp 519.260/RJ, referente à comissão de corretagem nos contratos de seguro, afirmando a similitude das situaçôes fáticas nos casos e dos argumentos trazidos pelas seguradoras e incor-

16 O Min. Sanseverino transcreve em seu voto o seguinte trecho da manifestação da Fazenda Nacional: "8. Como a Receita Federal constatou em diversas fiscalizações, e como já mencionado alhures, há uma contratação prévia por parte da construtora, que repassa toda a intermediação, em caráter exclusivo, à imobiliária, a qual realiza os serviços contratados mediante seus colaboradores. A intermediação é realizada, portanto, em função dos interesses da construtora e os corretores da imobiliária contratada ficam a serviço da construtora, inclusive para coletar informações sobre futuros clientes. 9. Tanto é assim que, em várias ocasiōes, a Receita Federal apurou que, somente após a concretização da venda, é celebrado um contrato de intermediação (de corretagem) que contém, geralmente, um anexo denominado 'Carta Proposta', em que estão relacionados os valores de comissão devidos pelo comprador aos corretores envolvidos na venda ou à imobiliária. Ressalte-se que, somente após a 'concretização' da venda, o comprador (pessoa física) assina o contrato com o corretor, do que se infere que esse contrato de intermediação seria apenas um termo de transferência de responsabilidade pelo pagamento dos serviços, contratados inicialmente pela construtora e, em grande parte, já finalizados (captação, orientação e convencimento do cliente). 10. Não se nega que ambos (construtora e comprador) acabam usufruindo dos serviços do corretor, mas, como alguns doutrinadores manifestam-se pelo entendimento de que os serviços devem ser pagos pelo contratante, a Receita Federal, em geral, autua as imobiliárias e construtoras pelo não faturamento de tais valores e pelo não pagamento das contribuiçôes previdenciárias referentes aos corretores”. 
poradoras, no sentido de que o serviço era prestado ao consumidor. Porém, como afirmou o Min. Sanseverino, "[e]sse argumento das seguradoras, contudo, não prevaleceu".

O voto, então, chega ao que se considerou o cerne do recurso especial, "a verificação da possibilidade de transferência pelo vendedor (incorporadora) ao comprador (consumidor), mediante cláusula contratual, da obrigação de pagar a comissão de corretagem". O Relator argumentou que a questão é especial, pois a validade da cláusula deve ser analisada à luz do Direito do Consumidor, já que se trata de relação de consumo.

O Min. Sanseverino afirmou que a transferência seria vantajosa às incorporadoras, também, na medida em que seria desnecessária a restituição da taxa de corretagem, "[...] caso haja o desfazimento da promessa de compra e venda, uma vez que o pagamento passa a ser feito diretamente ao corretor".

Feitas essas considerações, de forma abrupta, no parágrafo seguinte, o voto consignou, sem maiores explicações, que

[a]fasta-se, com isso, desde logo, a alegação de venda casada, pois ocorre apenas a terceirização dessa atividade de comercialização de unidades imobiliárias para profissionais do setor, concentrando-se a incorporadora na sua atividade de construçāo de imóveis (grifou-se).

O voto foi além e afirmou que essas vantagens obtidas pela incorporadora "[...] não causam prejuizo econômico para os consumidores, pois o custo da corretagem, mesmo nos contratos entre particulares, é normalmente suportado pelo comprador, seja embutido no preço, seja destacado deste" (grifou-se). Isto, segundo o Relator, faz parte da lógica do mercado imobiliário, "[...] pois a venda só produz lucro a incorporadora se o preço final do imóvel superar os seus custos, como restou bastante claro na audiência pública".

Para concluir pela validade da transferência do pagamento da comissão de corretagem ao consumidor, o Min. Sanseverino apontou outro importante fundamento da decisão, que "[...] o Direito do Consumidor, apesar de seu marcado caráter protetivo, não chega ao ponto de subverter a natureza onerosa das relações negociais no mercado de consumo, exigindo apenas transparência no seu conteúdo".

Nestes termos, o Min. inaugurou a terceira parte do voto, tratando do dever de informação imposto ao fornecedor. Pautado nos arts. 31, 46 e 52 do CDC e em doutrina, o Relator afirma que o dever de informação não é apenas um direito do consumidor, mas é, também, dever imposto aos fornecedores, sendo que 
para cumprir essa obrigação, deve a incorporadora informar ao consumidor, até o momento celebração $[$ sic $]$ do contrato de promessa de compra e venda, o preço total de aquisição da unidade imobiliária, especificando o valor da comissão de corretagem, ainda que esta venha a ser paga destacadamente.

Assim, considerou que a prática de informar ao consumidor que arcará com os custos da corretagem só depois do pagamento do sinal do negócio é prática abusiva, isto é, viola o CDC.

Pautado no art. 30 do CDC, o Min. Sanseverino deixou claro que toda publicidade e informação, suficientemente precisa, vincula o fornecedor, que, caso as viole, está sujeito ao cumprimento forçado, previsto no art. 35 da mesma Lei.

Com isso, teve o início da última parte do voto, tratando da validade da taxa SATI. Esta é a parte mais breve da fundamentação, totalizando apenas uma página e meia.

O Min. afirmou que a cobrança por serviços de assessoria técnica é abusiva, pois inerente aos negócios de compra e venda de imóveis na planta, o que violaria a boa-fé objetiva e os deveres de transparência e informação nas relações de consumo, nos termos do art. 51, inciso IV, do CDC. ${ }^{17}$ Convém lembrar que essa cobrança abusiva corresponde, em média, a $0,88 \%$ do valor do imóvel. ${ }^{18}$

17 Flávio Tartuce já defendia a abusividade da taxa SATI em 2014: "Cite-se de início, a cobrança da Sati (Serviço de Assessoria Técnica Imobiliária), destinada a pagar os advogados da construtora, em especial por terem redigido os contratos. $\mathrm{O}$ valor geralmente correspondente a $0,8 \%$ sobre o preço do imóvel adquirido. Ora, impor um procurador obrigatório ao consumidor é clausula abusiva, nula de pleno direito, por interpretação do art. 51, VII, da Lei n. 8.078/1990.

E, mesmo que assim não fosse, a cláusula, mais uma vez, viola a função social do contrato e a boa-fé objetiva, sendo nula por ilicitude do seu conteúdo (art. 166, II, do CC/2002). A abusividade é flagrante pelo fato de que o valor é cobrado até de especialistas em direito, como advogados, promotores, juízes e professores, que não necessitam de tal assessoria" (TARTUCE, Flávio. Do compromisso de compra e venda de imóvel. Questões polêmicas a partir da teoria do diálogo das fontes. Revista de Direito do Consumidor, ano 23, n. 93, maio-jun. 2014, p. 176).

Ainda, importante recordar que, nos termos do art. $15, \$ 6^{\circ}$, do Estatuto da OAB, é vedado aos advogados integrantes de uma mesma sociedade profissional representar, em juízo ou fora dele, cliente com interesses opostos.

18 Tal percentual é encontrado na Revista do IDEC, que realizou pesquisa empírica sobre a taxa SATI, com interessante metodologia: "Foram consideradas as dez maiores construtoras de imóveis residenciais do país, segundo o ranking ITC (consultoria especializada em mercado imobiliário): MRV, Gafisa, Brookfield, Direcional, Even, Cyrela, Rossi, Plaenge, Toledo Ferrari e Bueno Netto. Em seguida, foram procurados apartamentos dessas empresas, seja visitando o estande de vendas, seja fazendo contato telefônico ou via atendimento online. Como, em geral, os corretores só falam da taxa Sati quando o negócio está prestes a ser concretizado, lhes 
Esta narrativa, ainda que o leitor não tenha tido contato com os termos do voto do Min. Sanseverino, deixa transparecer alguns pontos em que a fundamentação do julgado poderia ter sido melhor fundamentada.

Note-se a citação feita ao REsp 519.260/RJ que, nos termos do próprio Min. Sanseverino, possuía similitude fática e jurídica com o recurso em comento, no qual a conclusão do STJ foi pela impossibilidade da transferência do pagamento da comissão de corretagem ao consumidor, pois deveria ser arcado pelo incumbente, que eram, na ocasião, as seguradoras. Porém, o voto não justifica os motivos pelos quais deixa de aplicar às incorporadoras o que ali foi decidido.

Outro problema do voto são as afirmações abruptas, que contrastam com o raciocínio que vinha sendo esboçado até então, como a de que a transferência do pagamento da comissão de corretagem não configuraria venda casada - deixando de mencionar, inclusive, o próprio art. 39 do CDC, no qual se define a venda casada e sua vedação - nem prejuízo ao consumidor. São parágrafos que "surgem" em meio a outras linhas de raciocínio.

A decisão, nesses pontos, teve fundamentação superficial e não foi por falta de subsídios teóricos. Os pareceres, frise-se mais uma vez, feitos por juristas de renome e colacionados aos autos, trouxeram argumentos sobre a venda casada.

A Professora Ada Pellegrini Grinover, em seu parecer, explica que, de fato, a transferência para o consumidor não configura venda casada, pois o contrato de corretagem é autônomo e o corretor independentemente, podendo ou não orbitar a compra e venda, desde que haja transparência e aquele seja devidamente informado do pagamento. ${ }^{19}$

No mesmo sentido, pela não configuração de venda casada, é o parecer do Professor Humberto Theodoro Júnior, para quem a prática só seria abusiva se diminuísse a liberdade de escolha do consumidor; porém, no caso das incorporadoras, haveria a possibilidade de o consumidor encontrar os bens da oferta separadamente (comprar o imóvel sem a participação de corretor). ${ }^{20}$

foi perguntado se haveria cobranças extras (além do valor do próprio imóvel). Em caso de resposta afirmativa, avaliou-se a maneira como a cobrança era colocada: obrigatória ou facultativa. Por fim, quando o corretor sugeria se tratar de cobrança obrigatória, questionou-se a natureza da cobrança, para verificar o novo discurso que ele adotaria”. Febre do imóvel. Revista do IDEC, n. 178, jun. 2013, p. 15.

19 GRINOVER, Ada Pellegrini. Parecer. São Paulo, 2015, p. 45, colacionados aos autos do REsp $1.551 .956 / \mathrm{SP}$.

20 THEODORO JR. Humberto. Comissão de corretagem na compra e venda de imóvel em construção. Inclusão no preço final do imóvel. Pagamento direto do comprador ao corretor. Expressa 
Dentre os pareceristas, é Araken de Assis quem melhor se detém na explicação da matéria. Para ele, a venda casada configura-se quando o consumidor é obrigado a comprar, junto com o produto principal, o produto secundário, como quando o consumidor, ao adquirir determinada impressora, é obrigado a comprar também o toner fornecido pela mesma vendedora. ${ }^{21}$

O jurista gaúcho continua o raciocínio e conclui que, no caso da compra e venda imobiliária, "[...] o serviço secundário (intermediação) antecede a aquisição do produto principal (compra e venda do imóvel)", ${ }^{22}$ não se verificando a venda casada, portanto.

Importante mencionar que o parecer em favor dos consumidores, elaborado pela Prof. Judith Martins-Costa, não trazia entre seus quesitos a questão da venda casada.

Não obstante os argumentos expressados nos respeitáveis pareceres sobre a prática não configurar venda casada, o assunto é complexo e controvertido na doutrina e jurisprudência. Para parte da doutrina, ${ }^{23}$ na medida em que se impede o consumidor de adquirir o imóvel na planta, caso ele se recuse a pagar comissão de corretagem, teríamos aí venda casada, com fundamento na interpretação literal do art. 39, inciso I, do CDC.

Logo, é lamentável que o Voto não tenha ido a fundo na análise da configuração ou não da venda casada. Isto porque, apesar de estar analisando caso de

previsão contratual. Possibilidade. Ausência de abuso. Respeito à função social do contrato e à boa-fé objetiva. Belo Horizonte, p. 24, colacionados aos autos do REsp 1.551.956/SP.

21 ASSIS, Araken de. Função social da corretagem imobiliária e inexistência de "venda casada" na compra e venda de imóveis. Porto Alegre, 2015, p. 25, colacionados aos autos do REsp 1.551.956/SP.

22 ASSIS, Araken de. Função social da corretagem imobiliária e inexistência de "venda casada" na compra e venda de imóveis. Porto Alegre, 2015, p. 25, colacionados aos autos do REsp 1.551.956/SP.

23 Nesse sentido, Marcelo Lima aponta que: "O pagamento da corretagem pelo adquirente não pode ser considerado uma prática abusiva per si. Mas, então, por qual razão esta prática comercial aparece como uma das principais questôes jurídicas que assolam o judiciário em matéria de incorporação imobiliária de unidades autônomas na planta?

Mais do que o ônus de quem vai, ou não, arcar com os valores da corretagem, o que merece maior destaque é que o adquirente não consegue adquirir imóvel na planta sem arcar com este valor. Em outras palavras, a incorporadora não fornece ao adquirente a faculdade de optar por comprar sem qualquer espécie de intermediação, o que é vedado pelo diploma consumerista (venda casada)" (LIMA, Marcelo C.M.P. O ônus do pagamento do serviço de corretagem e do serviço de assessoria técnico-imobiliária (Sati) nos contratos de compra e venda de unidades autônomas na planta. Revista de Direito do Consumidor, ano 23, n. 93, maio-jun. 2014, p. 186). O referido autor cita, inclusive, ação civil pública ajuizada pelo MP/SP que teria tido sentença de procedência pela venda casada. 
compra e venda na planta e de contrato de corretagem, certamente teria estabelecido quais os contornos jurídicos da prática abusiva de venda casada, e mais, poderia ter aclarado até mesmo o que é "venda casada" e, dessa forma, ter apreciado, por exemplo, se o fato de um contrato ser autônomo a desconfiguraria.

Também, chama atenção o argumento de que o custo da comissão seria suportado pelos consumidores de qualquer forma, pois faz parte da lógica do mercado.

Não se questiona aqui o argumento de que, no mercado, o preço da corretagem seria suportado pelo consumidor, ${ }^{24}$ seja da forma como vem sendo feito, com o pagamento direto ao corretor, seja de forma indireta, com o valor da corretagem incluído no preço final do produto - o que foi muito bem sintetizado pelo respeitável economista Gustavo Franco em seu parecer:

Em mercados grandes e compartimentalizados, as despesas de intermediação, comercialização e publicidade são essenciais para que a oferta dialogue com a demanda. É claro que estas despesas devem compor o preço final ofertado ao comprador. ${ }^{25}$

Nada obstante, ainda que argumentos de ordem econômica possam ser utilizados em decisões, é preciso que se revistam de seu caráter jurídico, sob pena de destituir a autonomia do Direito. Nunca é demais lembrar que o objeto da Ciência do Direito se restringe ao conjunto de normas válidas em dado momento e lugar. ${ }^{26}$

A compra e venda de imóveis e seus custos econômicos recebem a veste jurídica de contrato. Cumpre lembrar aqui as lições de Enzo Roppo, em obra clássica sobre o tema, quando ensina que os contratos "[...] reflectem sempre uma realidade exterior a si próprios, uma realidade de interesses, de relações, de situações económico-sociais, relativamente aos quais cumprem, de diversas maneiras, uma função instrumental". ${ }^{27}$

24 "O fornecedor pode incluir no preço do imóvel os gastos de material e pessoal, os riscos, os encargos, os tributos, os lucros almejados e todas as demais despesas que a sua atividade envolve. No entanto, fixando o preço do imóvel, o fornecedor tem o dever legal (art. 6º, III, do CDC) de prestar a informação adequada e clara sobre o montante exato pelo qual o consumidor deve pagar para adquirir o domínio do bem. O consumidor não tem vínculo contratual com o corretor e está obrigado a pagar tão somente o preço do imóvel e as respectivas despesas de escritura e registro. Qualquer valor além dos itens retrocitados é considerado indevido" (SANTANA, Héctor V. Pagamento de comissão de corretagem na compra e venda de imóvel: obrigação do fornecedor. Revista de Direito do Consumidor, ano 23, n. 93, maio-jun., 2014, p. 162).

25 FRANCO, Gustavo H. B. 10 teses econômicas sobre corretagem em vendas de imóveis na planta. Rio de Janeiro, 2016, p. 3, colacionados aos autos do REsp 1.551.956/SP.

26 REALE, Miguel. Liçôes preliminares de direito. 27. ed. São Paulo: Saraiva, 2002, passim.

27 ROPPO, Enzo. O contrato. Coimbra: Almedina, 2009, p. 7. 
Apenas se esboçasse esse raciocínio é que a afirmação feita pelo Min. Sanseverino, no sentido de que as partes estão no âmbito do Direito Privado, podendo, portanto, acertar a distribuição da comissão de corretagem, não ficaria "solta" na estrutura do Voto. Isto se daria em razão da conformação que o princípio da legalidade assume no Direito Privado, no qual é permitido aos particulares fazer tudo o que a Lei não proíba. ${ }^{28}$

De todo modo, não são nesses pontos que a decisão traz maiores implicações. É no que toca ao dever de informação que se encontra o real problema prático da decisão.

O Voto do Min. deixou de esclarecer a abrangência desse dever de informação, ${ }^{29-30}$ limitando-se a afirmar que a transferência do pagamento ao consumidor deve ser informada antes da celebração do contrato principal.

É cediço que o CDC, em seu art. 30, equiparou a publicidade e a informação "suficientemente precisas" à força vinculante da oferta. Aqui, as lições do Professor Antonio Junqueira de Azevedo são claras:

É interessante observar que, do ponto de vista teórico, o suporte fático da oferta é a declaração negocial e, portanto, ela é negócio jurídico. Já a informação ou a publicidade suficientemente precisa não contêm declaração negocial, mas são somente atos legalmente equiparados à oferta; logo, não são negócios jurídicos, e sim, atos a que a lei atribui efeitos negociais (à semelhança das chamadas 'relaçōes contratuais de

28 Nesse sentido, BANDEIRA DE MELLO, Celso Antonio. Curso de direito administrativo. 26. ed. São Paulo: Malheiros, 2009, p. 105: “Ao contrário dos particulares, os quais podem fazer tudo o que a lei não proíbe, a Administração só pode fazer o que a lei antecipadamente autorize".

29 "Em decorrência de tão grande oferta no mercado de consumo, o legislador busca assegurar direitos e deveres tanto para os consumidores quanto para o fornecedor. Os direitos do consumidor devem ser respeitados em qualquer fase da negociação, seja na fase pré ou pós-contratual, seja na oferta, publicidade de anúncios de imóveis ou mesmo no contrato, razão do dirigismo estatal imposto pelo Código de Consumidor, para o reestabelecimento do justo equilíbrio no mercado imobiliário" (MARTINS, Plínio. L.; RAMADA, Paula C, p. Overbooking imobiliário e os direitos do consumidor na aquisição de imóveis. Revista de Direito do Consumidor, ano 23, v. 91, jan.-fev. 2014, p. 138).

30 Em artigo publicado em 2014, a autora Luciana Pedroso Xavier, em coautoria com Marília Pedroso Xavier, manifestou-se justamente pela ilegalidade da cobrança dissimulada da comissão de corretagem, por ferir o direito básico à informação do consumidor, assegurado no art. 6o, III, do CDC. Nesse trabalho é explicado de modo mais pormenorizado quais as práticas adotadas pelas incorporadoras para camuflar tal cobrança (XAVIER, Luciana P.; XAVIER, Marília P. A ilegalidade da cobrança dissimulada da comissão de corretagem. In: STAUT Jr., Sérgio S. (Org.). Estudos em direito privado: uma homenagem ao Prof. Luiz Carlos Souza de Oliveira. Curitiba: Luiz Carlos Centro de Estudos Jurídicos, 2014, p. 89-104). 
fato’). Dessas diferenças, pode surgir uma série de consequências práticas, especialmente em matéria de vícios do consentimento (erro, dolo, coação). ${ }^{31}$

Dada essa abrangência, a questão merecia tratamento mais detido no julgamento em comento. Imagine-se a hipótese de outdoor conter determinado valor para uma unidade imobiliária na planta. Interessado, o consumidor se dirige ao stand da incorporadora e lá é informado, antes da celebração do contrato principal, que arcará com os custos da comissão de corretagem, que aumentarão em " $\mathrm{x}$ " $\mathrm{o}$ valor anunciado no outdoor. Aqui, o dever de informação foi cumprido? Nos termos expressos na decisão, o dever de informação estaria plenamente cumprido, pois o consumidor soube que arcaria com a comissão antes da pactuação do contrato principal.

Mas essa solução vai de encontro ao que dispõe o art. 30 do CDC, pois o outdoor traz informação suficientemente precisa acerca do preço. Na prática, o consumidor precisaria discutir a execução da oferta, levando ao Judiciário o problema.

\section{CONSIDERAÇÕES FINAIS}

Com base nas linhas acima escritas, fica evidente que, apesar de a competência constitucional do STJ ser para uniformizar interpretação de lei federal e o objetivo dos Recursos Repetitivos ser oferecer mais celeridade, isonomia e segurança jurídica no julgamento de Recursos Especiais que tratem da mesma controvérsia jurídica, lamentavelmente o tema da comissão de corretagem continua inconclusivo.

Isto porque, se, por um lado, louva-se a iniciativa de afetar um tema com tantas demandas e com resultados divergentes pelo Brasil, o que gerava insegurança jurídica, por outro, a tese jurídica firmada no REsp 1.599.511/SP ainda é fonte de dúvidas no momento de sua aplicação aos casos concretos.

Conforme anteriormente exposto, permanecem incertezas sobre em quais circunstâncias se entende ter sido cumprido o dever de informação do promitente-vendedor. Os casos de oferta do preço em outdoors, flyers e outros tipos de publicidade são emblemáticos dessa dificuldade prática. Ainda, podem ser citados os casos em que a comissão está prevista apenas no contrato e não no quadro-resumo e vice-versa, bem como no caso das cláusulas que estipulam esse dever e não são redigidas com destaque, tornando-se abusivas segundo o Código de Defesa do Consumidor.

31 AZEVEDO, Antonio Junqueira de. Responsabilidade pré-contratual no código de defesa do consumidor: estudo comparativo com a responsabilidade pré-contratual no direito comum. Revista da Faculdade de Direito da USP, v. 90, ano 1995, p. 131. 
Cumpre informar o desdobramento do tema/repetitivo n. 938, por meio do qual se originou o tema/repetitivo n. 960, cujo recurso representativo de controvérsia é o de n. 1.601.149/RS, afetado em 09.09.2016. Neste recurso se discute a transferência da comissão de corretagem na compra e venda do imóvel na planta, porém, restrita aos imóveis que façam parte do programa Minha Casa, Minha Vida. ${ }^{32}$ Segundo o Min. Sanseverino, que também é relator desse tema, as compras e vendas ocorridas no âmbito do programa Minha Casa, Minha Vida possuem "particularidades que merecem ser analisadas em afetação específica”. Todavia, apesar da diferença de poucos dias entre o julgamento do tema/repetitivo n. 938 e a afetação deste, não houve nenhuma indicação de que haveria ressalva nesse sentido.

Em decisão monocrática, o Min. Sanseverino estabeleceu como tese a ser debatida a "validade da transferência ao consumidor da obrigação de pagar a comissão de corretagem nas promessas de compra e venda celebradas no âmbito do programa 'Minha Casa, Minha Vida'”. Determinou, também, a suspensão de todos os processos pendentes que versassem sobre a questão, ressalvando, expressamente, "[...] as hipóteses de autocomposição, tutela provisória, resolução parcial do mérito e coisa julgada [...]”. Ao todo, estão suspensos 3.271 processos. ${ }^{33}$

O julgamento do tema/repetitivo n. 960 teve início em 28.02.2018. O Min. Sanseverino propôs a seguinte tese: "Abusividade de cláusula contratual que transfere ao consumidor a obrigação de pagar a comissão de corretagem nas promessas de compra e venda celebradas no âmbito do programa 'Minha Casa, Minha Vida'”. No seu entendimento, a cobrança da taxa poderia desvirtuar o programa habitacional por gerar custos não previstos e que poderiam ser um empecilho ao acesso à casa própria. ${ }^{34}$ Após pedido de vista do Min. Luis Felipe Salomão, em 11.04.2018, os autos estão conclusos, pendentes de julgamento, portanto. ${ }^{35}$

32 Sobre a questão habitacional e o programa Minha Casa, Minha Vida, cf. XAVIER, Luciana P. As teorias do patrimônio e o patrimônio de afetação na incorporação imobiliária. 2013. Dissertação (Mestrado em Direito). Faculdade de Direito, Universidade Federal do Paraná. Curitiba - Paraná, 2013, p. 98-102.

33 Para além do REsp 1.601.149/RS, o REsp 1.602.042/RS também foi afetado ao tema/repetitivo 960. As informaçōes sobre esses temas/repetitivos podem ser encontradas no seguinte link: <http://www.stj.jus.br/repetitivos/temas_repetitivos/pesquisa.jsp>. Acesso em: 25. abr. 2018.

34 STJ começa a julgar abusividade de taxa de corretagem no Minha Casa, Minha Vida. <http:// www.irib.org.br/noticias/detalhes/portal-jota-stj-comeca-a-julgar-abusividade-de-taxa-de-corretagem-no-minha-casa-minha-vida>. Acesso em: $1^{\circ}$ mar. 2018.

35 Até a finalização da escrita do presente artigo, o julgamento não havia sido concluído. 
Considerando a missão constitucional do STJ, é curioso imaginar as possíveis repercussões que o julgamento desse tema/repetitivo possa trazer, já que não se vislumbra uma diferença na questão de direito ali debatida, a qual foi objeto desta pesquisa. Há possibilidade, inclusive, de decisôes contraditórias.

Há, também, o problema da insegurança jurídica: como ficam aqueles consumidores que adquiriram um imóvel pelo Minha Casa, Minha Vida, pagaram pela comissão de corretagem, ajuizaram uma demanda para reavê-la e, após o julgamento do tema/repetitivo n. 938, desistiram de eventual recurso, caso se entenda no tema/repetitivo n. 960 que a comissão, nesse âmbito, era abusiva? Por configurar precedentes, ${ }^{36}$ a importância dos recursos repetitivos seria justamente a de viabilizar maior uniformidade, previsibilidade e igualdade das decisôes. ${ }^{37}$ Sendo assim, espera-se que o tema da cobrança de corretagem em compra e venda de imóvel em incorporação imobiliária receba a merecida atenção do Judiciário e que lhe seja dada interpretação compatível com a jurisprudência estável, íntegra e coerente almejada pelo Código de Processo Civil de 2015. ${ }^{38}$

\section{REFERÊNCIAS}

ASSIS, Araken de. Função social da corretagem imobiliária e inexistência de "venda casada" na compra e venda de imóveis. Porto Alegre, 2015, colacionados aos autos do REsp $1.551 .956 / \mathrm{SP}$.

AZEVEDO, Antonio Junqueira de. Responsabilidade pré-contratual no código de defesa do consumidor: estudo comparativo com a responsabilidade pré-contratual no direito comum. Revista da Faculdade de Direito da USP, v. 90, ano 1995.

BANDEIRA DE MELLO, Celso Antonio. Curso de direito administrativo. 26. ed. São Paulo: Malheiros, 2009.

FRANCO, Gustavo H. B. 10 teses econômicas sobre corretagem em vendas de imóveis na planta. Rio de Janeiro, 2016, colacionados aos autos do REsp 1.551.956/SP.

FREYRE, Gilberto. Oh de casa! em torno da casa brasileira e de sua projeção sobre um tipo nacional de homem. Rio de Janeiro: Artenova, 1979.

36 Art. 927, CPC/15: “Os juízes e os tribunais observarão: (...) III - os acórdãos em incidente de assunção de competência ou de resolução de demandas repetitivas e em julgamento de recursos extraordinário e especial repetitivos".

37 PUGLIESE, William Soares. Precedentes e a civil law brasileira: interpretação e aplicação do novo código de processo civil. São Paulo: RT, 2016, p. 99.

38 Art. 926, caput, CPC/15: "Os tribunais devem uniformizar sua jurisprudência e mantê-la estável, íntegra e coerente”. 
•• Direito Civil: Estudos | Coletânea do XV Encontro dos Grupos de Pesquisa - IBDCivil

GRINOVER, Ada Pellegrini. Parecer. São Paulo, 2015, colacionados aos autos do REsp 1.551.956/SP.

GLOBO. O auge e a queda do mercado imobiliário em uma década. G1. 01.04.2016. Disponível em: <http://g1.globo.com/especialpublicitario/zap/imoveis/noticia/2016/04 /o-auge-e-queda-do-mercado-imobiliario-em-uma-decada.html>. Acesso em: 21 abr. 2018.

LEONARDO, Rodrigo Xavier. Redes contratuais no mercado habitacional. São Paulo: RT, 2003.

LIMA, Marcelo C.M.P. O ônus do pagamento do serviço de corretagem e do serviço de assessoria técnico-imobiliária (Sati) nos contratos de compra e venda de unidades autônomas na planta. Revista de Direito do Consumidor, ano 23, n. 93, maio-jun., 2014.

MARTINS, Plínio. L.; Ramada, Paula C, p. Overbooking imobiliário e os direitos do consumidor na aquisição de imóveis. Revista de Direito do Consumidor, ano 23, v. 91, jan.fev., 2014.

MENEZES, Fabiane Ziolla. Cresce a retomada de imóveis por inadimplência. Saiba como escapar dessa. Gazeta do Povo, 05.04.2017. Disponível em: <http:/www.gazetadopovo. com.br/economia/financas-pessoais/cresce-a-retomada-de-imoveis-por-inadimplencia-saiba-como-escapar-dessa-8g7e4h812l2c79jwqlh8x6nfo>. Acesso em: 21 abr. 2018.

REALE, Miguel. Lições preliminares de direito. 27. ed. São Paulo: Saraiva, 2002.

ROPPO, Enzo. O contrato. Coimbra: Almedina, 2009.

SANTANA, Héctor V. Pagamento de comissão de corretagem na compra e venda de imóvel: obrigação do fornecedor. Revista de Direito do Consumidor, ano 23, n. 93, maiojun., 2014.

TARTUCE, Flávio. Do compromisso de compra e venda de imóvel. Questões polêmicas a partir da teoria do diálogo das fontes. Revista de Direito do Consumidor, ano 23, n. 93, maio-jun., 2014.

PONTES, Daniele Regina. $O$ direito à moradia: entre o tempo e o espaço das apropriações. 2013. Tese (Doutoramento em Direito). Faculdade de Direito, Universidade Federal do Paraná. Curitiba - Paraná, 2013, $215 f$.

PUGLIESE, William Soares. Precedentes e a civil law brasileira: interpretação e aplicação do novo código de processo civil. São Paulo: RT, 2016.

XAVIER, Luciana P. As teorias do patrimônio e o patrimônio de afetação na incorporação imobiliária. 2013. Dissertação (Mestrado em Direito). Faculdade de Direito, Universidade Federal do Paraná. Curitiba - Paraná, 2013, $179 f$.

XAVIER, Luciana P.; XAVIER, Marília P. A ilegalidade da cobrança dissimulada da comissão de corretagem. In: STAUT Jr., Sérgio S. (Org.). Estudos em direito privado: uma homenagem ao Prof. Luiz Carlos Souza de Oliveira. Curitiba: Luiz Carlos Centro de Estudos Jurídicos, 2014, v. I, p. 89-104. 